\title{
Postglacial Fire Frequency AND ITS RELATION TO LONG-TERM VEGETATIONAL AND Climatic Changes in Yellowstone Park
}

\section{CATHY WHITLOCK $\downarrow$ DEPARTMENT OF GEOGRAPHY UNIVERSITY OF OREGON $\downarrow$ EUGENE}

\section{$\downarrow \quad$ INTRODUCTION}

The paleoecologic record provides unique insights into the response of communities to environmental perturbations of different duration and intensity. Climate is a primary agent of environmental change and its long-term effect on the vegetation of the Yellowstone/Grand Teton region is revealed in a network of pollen records. Fire frequency is controlled by climate, and as climate changes so too does the importance of fire in shaping spatial patterns of vegetation. The prehistoric record of Yellowstone's Northern Range, for example, shows the response of vegetation to the absence of major fires in the last 150 years (Whitlock et al., 1991; Engstrom et al., 1991, 1994). In longer records spanning the last 14,000 years, periods of frequent fire are suggested by sediments containing high percentages of fire-adapted trees, including lodgepole pine and Douglas-fir, and high amounts of charcoal (Whitlock, 1993; Whitlock and Bartlein, 1993; Whitlock et al., 1995; Millspaugh and Whitlock, 1995).

The primary research objective has been to study the vegetational history of the Yellowstone region and examine the sensitivity of vegetation to changes in climate and fire frequency on different time scales. This information is necessary to understand better the relative effects of climate, natural disturbance, and human perturbation in the present and future. Fossil pollen and plant macrofossils from dated-lake sediment cores provide information on past vegetation and climate. The frequency of charcoal particles and other fire indicators in dated lake-sediment cores offer evidence of past fires. Studies of future climate and vegetation in the Yellowstone region were based on climate simulations produced by general circulation models that incorporate a doubling of carbon dioxide and an equilibrium model to project potential range displacement of selected tree taxa. Relations between present distributions of tree taxa and climate were established by the use of response surfaces.

The study has been divided into three parts: (1) an investigation of the vegetation history of Yellowstone National Park (YNP), (2) an analysis of charcoal accumulation in lakes following the 1988 fires and a reconstruction of fire history in central YNP on long time scales, and (3) a study of the potential ranges of tree taxa in the future with global increases in atmospheric carbon dioxide. A final report to the UW-NPS Research Center describes the methodology and findings in detail (Whitlock et al., 1994).

\section{$\downarrow \quad$ STUdY AREA}

Several lakes and fens have been used to study the long-term vegetation history of YNP and Grand Teton National Park (GTNP) (see Whitlock, 1993; Whitlock et al., 1995; Whitlock and Bartlein, 1993 for site locations). Eight sites in YNP were selected for the post-1988 charcoal study to provide a representative sampling of conditions in 1988 and 
vegetation types. The charcoal study lakes are generally small $\left(<0.5 \mathrm{~km}^{2}\right)$ and have minor or no inflowing streams. Five of the lakes lie in the 1988 burned region (Grizzly Lake, Cascade Lake, Duck Lake, Goose Lake, and Lake of the Woods). Three lakes lie outside the burned region (Wrangler Lake, Sylvan Lake, and Dryad Lake). Sites used to study fire history include Dryad Lake, Duck Lake, Mallard Lake, Grizzly Lake, Cygnet Lake, and West Thumb of Yellowstone Lake (see Millspaugh and Whitlock, 1995) and Slough Creek Pond.

\section{METHODS}

\section{FIELD WORK}

Surface sediment was collected with a 5$\mathrm{cm}$-diameter gravity sampler from an inflatable raft in July and August from the eight study lakes. Short cores were collected with a meter-long piston corer from a raft anchored in the deepest part of the lake (Wright, et al. 1983). These cores were subsampled at $1-\mathrm{cm}$ intervals in the field, and samples were stored in plastic bags. Long cores were recovered with a modified Livingstone sampler from an anchored platform in the deepest water or from the fen surface adjacent to the lake. Long cores were extruded and wrapped in the field.

\section{SHORT CORE AND SURFACE SAMPLE ANALYSIS}

Charcoal analysis was confined to macroscopic particles, using methods described by Millspaugh and Whitlock (1995). Surface sediment was sampled volumetrically, and the samples were disaggregated in a dilute Calgon solution and gently sieved through $0.250-\mathrm{mm}-$ and $0.125-\mathrm{mm}-\mathrm{mesh}$ screens. The sediment fraction $<0.125 \mathrm{~mm}$ in size was saved for possible analysis in the future. Charcoal for each size fraction was tallied under a binocular microscope. Charcoal quantities were calculated as number of charcoal pieces $/ \mathrm{cm}^{2}$. Contiguous 1-cm samples taken from the short cores were analyzed in the same way as the surface samples and the data are presented as charcoal pieces $/ \mathrm{cm}^{2} / \mathrm{yr}$.

Magnetic susceptibility was measured with a continuous-core magnetic susceptibility sensor.
Measurements were taken every $\mathrm{cm}$ for short cores from Goose Lake, Mallard Lake, Dryad Lake, Duck Lake, Cygnet Lake, and Grizzly Lake. The lead-210 method was used to date sediments spanning the last 150-200 years in short cores. Lead-210 was measured through its granddaughter product ${ }^{210} \mathrm{Po}$, with ${ }^{208} \mathrm{Po}$ added as an internal yield tracer. Dates and sedimentation rates were determined by $\mathrm{Dr}$. William Schell (Department of Radiation Chemistry, University of Pittsburgh) and Dr. Daniel Engstrom (Limnological Research Center, University of Minnesota), using the constant rate of supply model (Appleby and Oldfield, 1978).

\section{LONG CORE ANALYSIS}

Long cores were sliced longitudinally, and each core segment was described. Samples of 0.5 $\mathrm{cm}^{3}$ size were taken at regular stratigraphic intervals for pollen and sediment analyses. One set of samples was used to determine the percentage of organic carbon and carbonate in the cores by measuring the weight-loss after ashing the samples at $550^{\circ}$ and $900^{\circ} \mathrm{C}$.

A second set of samples was taken for pollen analysis. All pollen samples were treated to standard laboratory procedures (Faegri et al. 1989, Cwynar et al. 1979). A tracer of Lycopodium pollen was added to each sample to calculate pollen concentration (grains $/ \mathrm{cm}^{3}$ ) and pollen accumulation rates (grains $/ \mathrm{cm}^{2} / \mathrm{yr}$ ). Preparations were mounted in silicon oil and examined at magnifications of 400 and $1000 x$.

Identification of fossil pollen was based on published atlases and the pollen reference collection at University of Oregon. Between 300 and 500 terrestrial pollen were identified and tallied per stratigraphic level. Pollen percentages were calculated for each sample. A denominator of total terrestrial pollen was used to calculate the percentage of each terrestrial pollen type. The sum of all pollen and spores (including aquatic taxa) was used to calculate the percentage of aquatic and fen taxa.

Radiocarbon dating of the sediment and tephrochronology were the main methods for calculating the age of pollen stratigraphic and lithologic changes of the last 14,000 years. 


\section{RESULTS AND DISCUSSION}

The vegetation history was based on fossil pollen records collected from a network of lakes and wetlands in the YNP/GTNP region. The fossil records indicate that alpine meadow communities with birch and juniper, were present between 14,000 and 11,500 yr B.P. This early assemblage implies a lowering of modern treeline by at least $600 \mathrm{~m}$ and a climate that was $5-6^{\circ} \mathrm{C}$ colder than present. Between 11,500 and 10,500 yr B.P., increased temperature and winter precipitation allowed spruce, fir, and whitebark pine to spread into areas underlain by andesite and nonvolcanic bedrock and form a subalpine forest.

Between 10,000 and 9500 yr B.P., lodgepole pine forest developed everywhere in the Yellowstone region in response to warming. The subsequent climate history of the Northern Range, however, is different from that of the rest of YNP/GTNP. The period from 9500 to 5000 yr B.P. support forests of pine, juniper, and birch in mesic settings in the Northern Range. The inferred vegetation is interpreted as evidence of wetter-thanpresent conditions in the early Holocene. In the late Holocene, the expansion of Douglas-fir and grass implies gradual aridity and the establishment of the modern vegetation. In southern Yellowstone National Park, the Absaroka region, the Bechler region, and Grand Teton National Park, Douglas-fir and aspen were more abundant between 9500 and 5000 yr B.P. The pollen and charcoal data suggest an early-Holocene climate that was warmer and drier than that of today and more frequent fires. During the late Holocene, a mixed forest of spruce, pine, and fir replaced lodgepole pine and Douglas-fir on andesitic and nonvolcanic terrain. This change is attributed to the onset of cooler moister conditions. Many sites in southern Yellowstone National Park and Grand Teton National Park suggest an opening of the forest in the last 2000 years, perhaps as a result of increased drought or a change in disturbance regime.

The vegetational history is attributed to a combination of climatic and nonclimatic controls operating on different temporal and spatial scales. Climatic changes brought about by the retreat of Laurentide ice and variations in the seasonal cycle of radiation explain the broad patterns of vegetational change on millennial time scales. On shorter time scales and small spatial scales, substrate differences and migration history shaped the vegetational variability. In the Yellowstone Lake region, this hierarchy of controls and responses may have resulted in early Holocene conditions that favored human activities in summer, but cold winters may have limited year-round occupation.

\section{THE STUDY OF FIRE HISTORY IS DIVIDED INTO THREE PARTS}

(a) A study of the depositional processes that incorporate charcoal into lake sediments. An examination of charcoal accumulation following the 1988 fires shows that charcoal levels increased in lake sediments between 1989 and 1993 (Whitlock and Millspaugh, 1995; Whitlock et al., in press) (Fig. 1). We continue to monitor lakes to determine how long charcoal accumulates following a fire event. This results suggest that much of the charcoal in lake records is secondary, i.e., introduced from burned slopes and trees and from the littoral zone. Comparison of charcoal levels at different water depths and in different lakes indicated that sediment cores for fire history studies should come from the center of deep lakes with steep catchments. The modern study also suggests caution in inferring fire size or intensity from charcoal data. Factors, such as the introduction, transport, and burial of charcoal within the lake, diluted the primary signal, and the amount of sedimentary charcoal from a particular fire event is controlled as much by processes within the lake as by the amount of biomass that was burned.

Unburned
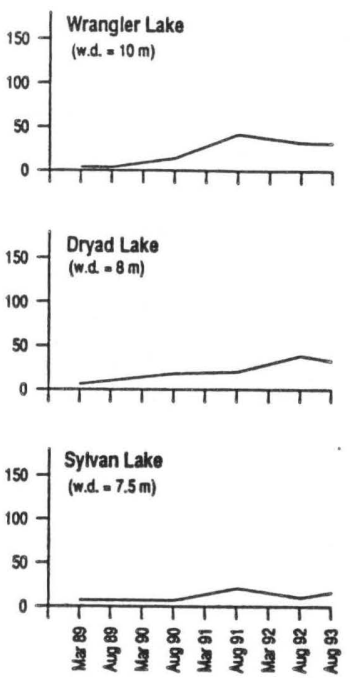

Figure 1 
Burned

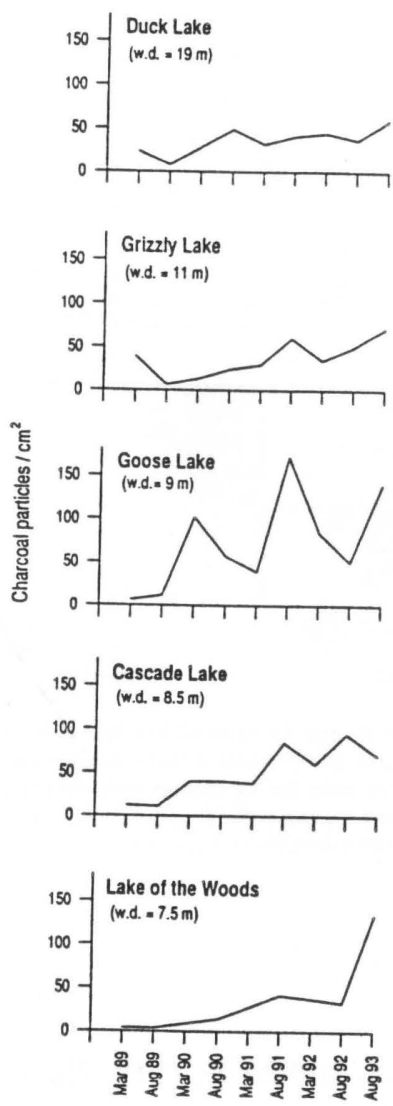

Sampling period

Figure 1. Comparison of 1988 charcoal abundance in deep-water sediments of study lakes in YNP from 1989 to 1993 . Note that in all lakes the levels of charcoal has increased. Sylvan Lake, Wrangler Lake, and Dryad Lake lie in unburned watersheds, and the increase in charcoal at these sites is attributed to redeposition of material from the littoral zone (from Whitlock and Millspaugh, 1995)

(b) An analysis of the fire history of last 750 years from the Central Plateau. Charcoal records from four small lakes provide a history of fires within particular watersheds (Millspaugh and Whitlock, 1995). These data were also compared with a charcoal record from the West Thumb of Yellowstone Lake that disclosed the regional fire history. The records indicate that large areas of the Central Plateau burned in 1988, ca. 1700, ca. 1560 , and ca. 1440. From ca. 1220 to 1440 and ca. 1700 to 1987 , intermediate to small areas burned. The near absence of fires in the 20th century prior to 1988 is evident in the charcoal record and corroborates conclusions based on dendrochronologic records (Romme, 1982; Romme and Despain, 1989) (Table 1). The fire frequency on the Central Plateau over the last 750 years shows no periodicity that would indicate a long-term fire cycle.

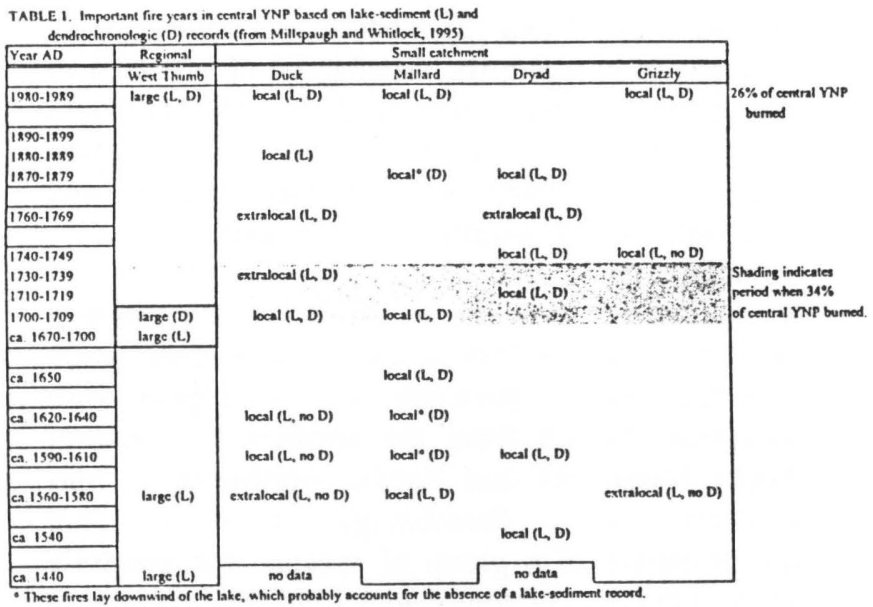

(c) A study of fire frequency, vegetation changes, and climate history of the last 12,500 years. Charcoal and pollen records from Cygnet Lake highlight the role of long-term climatic changes in determining fire regimes on the Central Plateau (Whitlock and Millspaugh, in press; S. Millspaugh, Ph.D. dissertation, in prep.). Following deglaciation, cooler and wetter-than-present conditions supported tundra in the region. The fire regime was characterized by infrequent small fires, much like present-day Arctic regions. As the climate warmed and conifers colonized the YNP, the regional fire frequency increased. Fires were uncommon on the Central Plateau, until the arrival of lodgepole pine ca. 10,000 yr B.P. From 9300 to $8300 \mathrm{yr}$ B.P., conditions were warmer and drier than at present and the forest experienced frequent, probably small fires. Local fires were infrequent after 8000 yr B.P. although fires occurred in the region as a whole. From 7000 yr B.P. to the present day, the disturbance regime has been characterized by large, stand-replacing fires every $150-500$ years. In the last 900 years, for example, the charcoal record suggests major fires in the mid $1500 \mathrm{~s}$, between 1730 and 1750, and in 1988. The nonstationarity in the occurrence of fires at Cygnet Lake argues against long-term fire cycles per se. Rather, the data suggests that fire regimes fluctuate through time as a nonlinear response to changes in climate.

The third component of the research project compares the environmental history of YNP with the potential future environmental changes that might occur in the region with a doubling of atmospheric carbon dioxide (Bartlein et al., in review). This investigation uses (1) climate simulations produced 
by general circulation models to infer regional climate changes and (2) modern vegetation-climate relations to compare the distribution of tree taxa in the past, present, and future. The potential distributions of selected tree taxa in the YNP region indicated a combination of elevational and directional range adjustments in response to future climatic conditions (Fig. 2). The resultant communities have no analogue in the current vegetation, because they mix low- and high-elevation montane species presently in the region with extralocal species from the northern and central Rocky Mountains and Pacific Northwest. Pinus contorta and Pseudotsuga menziesii are representative of a group of species that presently grow in the Yellowstone region, and they experience only modest changes in range under future simulated conditions. Quercus gambelii, Juniperus occidentalis, and Pinus ponderosa are absent today in Yellowstone National Park, but warm dry summers in the future simulation extend the range of these species to low elevations in the region. Projected mild wet winters and warm dry summers also shift the distribution of Larix occidentalis, Tsuga heterophylla, and Thuja plicata southeastward of their present limit. The complexity and extent of the projected environmental changes generate issues in the management and natural reserves that may be difficult to resolve.
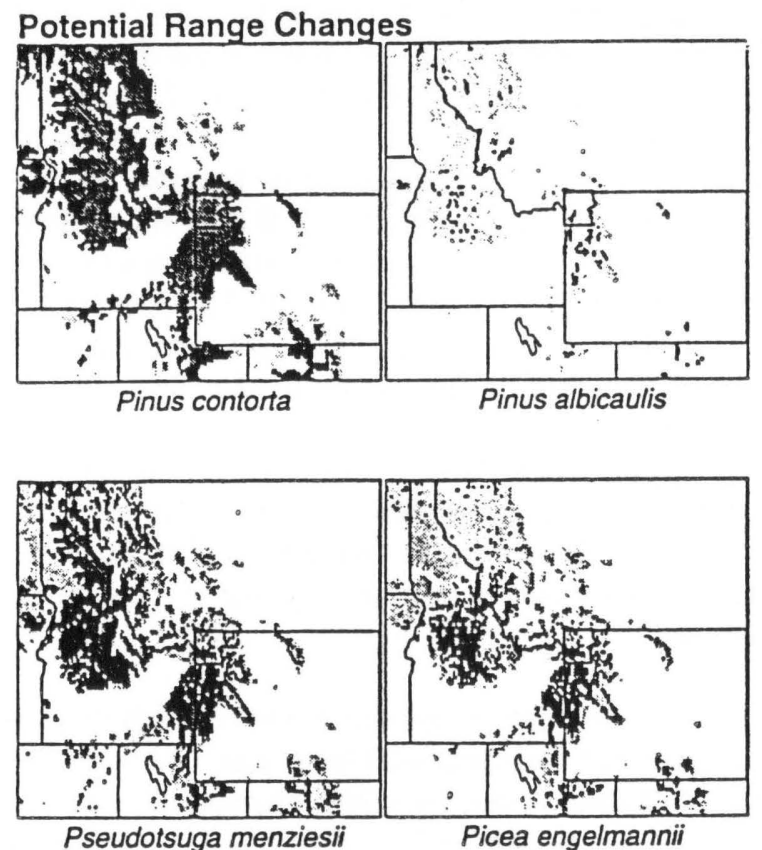
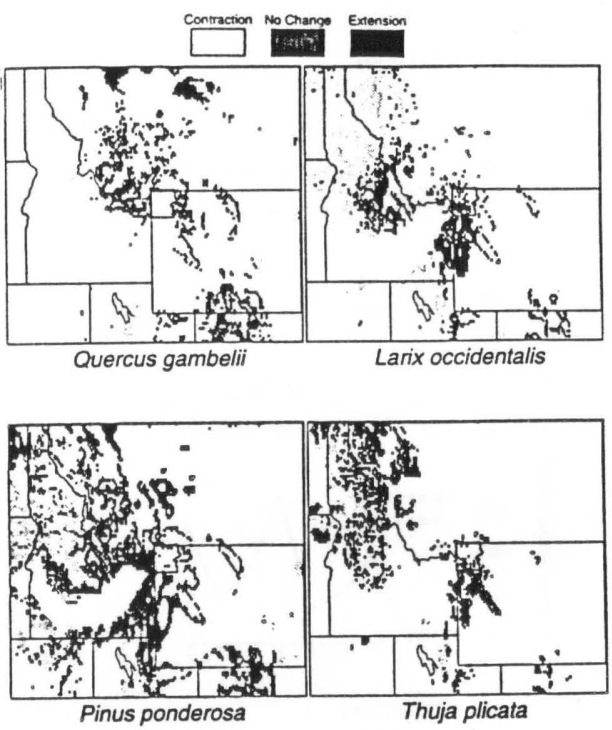

Figure 2. Potential range changes for selected tree taxa in the YNP region Light shading indicated grid points where a taxon occure under the present climate, but does not occur under $2 \mathrm{xCO}_{2}$ climate; dark shading indicated grid points where a taxon does not occur under the present climate, but does occur under the $2 \mathrm{xCO}_{3}$ climate (from Bartlein et al., in review )

\section{Literature Cited}

Appleby, P.G. and Oldfield, F. 1978. The calculation of lead-210 dates assuming a constant rate of supply of unsupported ${ }^{210} \mathrm{~Pb}$ to the sediment. Catena 5: 1-8.

Bartlein, P.J., C. Whitlock, and S. Shafer. In review. Future climate in the Yellowstone National Park region and its potential impact on vegetation. Conservation Biology.

Cwynar, L.C., Burden, E., and McAndrews, J.H. 1979. An inexpensive method for concentrating pollen and spores from finegrained sediments. Canadian Journal of Earth Sciences 16: 1115-1120.

Engstrom, D.R., Whitlock, C., Fritz, S.C., and Wright, H.E., Jr. 1991. Recent environmental changes inferred from the sediments of small lakes in Yellowstone's Northern Range. Journal of Paleolimnology 5: 139-174. 
Engstrom, D.E., C. Whitlock, S. C. Fritz, S.C., and H. E. Wright, Jr. 1994. Reinventing erosion in Yellowstone's northern range. Journal of Paleolimnology 10: 159-161.

Faegri, K., Kaland, P.E., and Krzywinski, K. 1989. Textbook of pollen analysis. John Wiley and Sons, New York.

Millspaugh, S.H. and Whitlock, C. 1993. A longterm fire history of Yellowstone National Park reconstructed from lake sediment cores [abstract]. The ecological implications of fire in greater Yellowstone, Second Biennial Scientific Conference on the Greater Yellowstone Ecosystem, September 19-21. National Park Service, Yellowstone National Park.

Millspaugh, S.H., and Whitlock, C. 1995. A 750-yr fire history based on lake sediment records in central Yellowstone National Park. The Holocene, in press.

Romme, W.H. 1982. Fire and landscape diversity in subalpine forests of Yellowstone National Park. Ecological Monographs 52: 199-221.

Romme, W.H., and Despain, D.G. 1989. Historical Perspective on the Yellowstone Fires of 1988. BioScience 39: 695-699.

Whitlock, C. 1993. Postglacial vegetation and climate of Grand Teton and southern Yellowstone National Parks. Ecological Monographs 63: 173-178.

Whitlock, C. 1994. Long-term vegetational response to climatic change and edaphic conditions in Yellowstone National Park. In Plants and Their Environments: Proceedings of the First Biennial Scientific Conference on the Greater Yellowstone Ecosystem. National Park Service Technical Report NPS/NRYELL/NRTR, 301-304.

Whitlock, C., and Bartlein, P. J. 1993. Spatial variations of Holocene climatic change in the Yellowstone region. Quaternary Research 39: 231-238.

Whitlock, C., Bartlein, P. J., and Van Norman, K. J. 1995. Stability of Holocene climate regimes in the Yellowstone region. Quaternary Research 43, 433-436.
Whitlock, C., Bradbury, J. P., and Millspaugh, S. H. in press. Controls on charcoal distribution in lake sediments: case studies from Yellowstone National Park and Northwestern Minnesota. In Sediment Records of Biomass Burning and Global Change (J.S. Clark, H. Cachier, J.G. Goldhammer, and B.J. Stocks, eds). Springer Verlag.

Whitlock, C., Fritz, S.C., and Engstrom, D.R. 1991. A prehistoric perspective on Yellowstone's Northern Range. in R.B. Keiter and M.S. Boyce, editors. The Greater Yellowstone Ecosystem: Redefining America's Wilderness Heritage, pp. 289-305. Yale University Press.

Whitlock, C., and Millspaugh, S. H.. 1995. Testing assumptions of fire history studies: an examination of modern charcoal accumulation in Yellowstone National Park. The Holocene 6.

Whitlock, C., and Millspaugh, S. H. in press. Holocene vegetation and fire history of the Greater Yellowstone Ecosystem; with emphasis on the Yellowstone Lake region. submitted to "Human Settlement of the Foothill-Mountain Environments" Proceedings of the Rocky Mountain Anthropology Conference in Jackson WY, Sept. 30-Oct. 2, 1993.

Whitlock, C., Millspaugh, S.H., Bartlein, P.J., and Shafer, S. 1994. Postglacial fire frequency and its relation to long-term vegetational and climatic changes in Yellowstone national Park. Final Report to the University of Wyoming-National Park Service Research Center.

Wright, H. E., Jr., Mann, D. H. and Glaser, P. H.. 1983. Piston cores for peat and lake sediments. Ecology 65: 657-659. 